\title{
PEMFC Application in a Gliding Arc Plasam-Catalysis Reforming System Using Biogas
}

\author{
Mun Sup Lim, Young Nam Chun \\ BK21 Team for Hydrogen Production, Department of Environmental Engineering, Chosun University, \\ Gwangju, Korea \\ E-mail: ynchun@chosun.ac.kr \\ Received December 27, 2010; revised March 30, 2011; accepted April 8, 2011
}

\begin{abstract}
In this study, bio-waste gas is converted to sustainable hydrogen energy in good quality and low pollution. In addition, generated highly concentrated hydrogen is applied to fuel cell (PEMFC) to resolve environmental and energy crisis issue via gliding arc plasma system. Parameters that can affect the reforming performance of bio-gas in gliding arc plasma system were studied. Especially, the optimal operating condition in water gas shift reactor and preferential oxidation reactor for $\mathrm{CO}$ removal was proposed. For the parametric researches, change in steam feed amount and temperature change in catalyst bed in water gas shift reactor were studied. For the preferential oxidation reactor, air input flow rate change and temperature variation in catalyst bed were evaluated. The optimal operating conditions for gliding arc plasma reforming system are proposed as $6: 4$ of biogas component ratio (i.e., $\mathrm{CH}_{4}: \mathrm{CO}$ ), 3 of steam/carbon ratio, $16 \mathrm{~L} / \mathrm{min}$ of total gas flow rate, and $2.4 \mathrm{~kW}$ of input electric power. Where, the concentration of biogas that passed each reactor shows

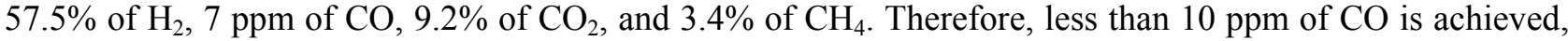
and this system can be applicable for PEMFC.
\end{abstract}

Keywords: $\mathrm{H}_{2}$ Concentration, CO Removal, Water Gas Shift, Preferential Oxidation, Biogas Reforming

\section{Introduction}

Recent depletion of fossil-based fuel has brought the significant issues, such as energy crisis, global warming, and environmental hazards. For the countermeasure, renewable energies have been focused.

Among the renewable energy sources, bio-waste gas is created from landfills, waste water disposal plant, and anaerobic metabolism of organic material. Biogas shows the different component ratio by types, but about $55 \%$ $70 \%$ of $\mathrm{CH}_{4}, 27 \%-40 \%$ of $\mathrm{CO}_{2}$, less than $1 \%$ of hydrogen, and $3 \%$ of $\mathrm{H}_{2} \mathrm{~S}$, etc are consisted. By reforming this bio energy to hydrogen energy, the environment-friendly system can be established. In addition, biogas reforming for fuel cell application exhibits high energy efficiency and good environment friendliness [1].

Polymer electrolyte membrane fuel cell can be used with not only pure hydrogen but also mixed gases of highly pure hydrogen. Direct application of hydrogen faces the danger to fire, and hydrogen reforming is widely adopted. For the reforming methods, steam reforming, partial oxidation, autothermal reforming, etc. are used to generate synthetic gas. Where, synthetic gas is composed of hydrogen, carbon dioxide, steam, and carbon monoxide. However, carbon monoxide can bring critical impact on the reliability of fuel cell. Therefore, water gas shift reaction and preferential oxidation are used to reduce the concentration of carbon monoxide less than $10 \mathrm{ppm}$ for the application on fuel cell $[2,3]$.

Many techniques have been developed, and gas phase plasma refers the state of separation with electron and cationic ion at high temperature. Plasma means a neutral gas with same number of positive and negative charges even for the high separation of electrical charges. Generally, plasma is classified as thermal plasma (high pressure or equilibrium plasma) and non-thermal plasma (low pressure or non-equilibrium plasma) [4]. Especially, gliding arc discharge (low plasma) can control the reaction state in low pressure, and features high conversion rate and energy efficiency. It has been noticed as new and environment-friendly alternative [5].

Gliding arc plasma reforming system, which is prepared laboratory space, has quick response type, and can be applicable to various types of fuel and biogases. In 
addition, gliding arc plasma-catalysis reactor is used for high conversion rate and consistent operation in optimal condition. From this setup, highly concentrated hydrogen and carbon monoxide were created. Water gas shift reactor and preferential oxidation reactor are implemented to reduce the concentration of carbon monoxide down to less than $10 \mathrm{ppm}$ for the application on fuel cell.

In this study, to reduce carbon monoxide content from gliding arc plasma-catalysis reactor, which can produce highly concentrated hydrogen with quick start feature, gliding arc plasma reforming system with water gas shift reactor and preferential oxidation reactor was designed and prepared.

Highly concentrated hydrogen, which is prepared with gliding arc plasma reforming system from biogas, is introduced to water gas shift reactor. Catalyst bed temperature and effect of steam feed amount was evaluated. In addition, reformed gas is introduced to preferential oxidation reactor along with different catalyst bed temperatures and air input flow rates. In addition, the optimal operating condition and starting performance with less than $10 \mathrm{ppm}$ of $\mathrm{CO}$ concentration was determined after passing water gas shift reactor and preferential oxidation reactor. Measurements on the concentration of reforming gas will provide the fundamental data on biogas system for fuel cell using gliding arc plasma reforming system.

\section{Experimental Apparatus and Method}

\subsection{Therretical Backgrounds on Reforming Reaction}

1) Plasma creaking reaction [6]

$$
\begin{gathered}
\mathrm{CH}_{4}=\mathrm{C}+2 \mathrm{H}_{2} \quad \Delta \mathrm{H}=+75 \mathrm{~kJ} / \mathrm{mol} \\
2 \mathrm{CO}=\mathrm{C}+\mathrm{CO}_{2} \quad \Delta \mathrm{H}=-172 \mathrm{~kJ} / \mathrm{mol} \\
\mathrm{CO}+\mathrm{H}_{2}=\mathrm{C}+\mathrm{H}_{2} \mathrm{O} \quad \Delta \mathrm{H}=-132 \mathrm{~kJ} / \mathrm{mol}
\end{gathered}
$$

2) Steam reforming reaction [7]

$$
\mathrm{CH}_{4}+\mathrm{H}_{2} \mathrm{O}=3 \mathrm{H}_{2}+\mathrm{CO} \quad \Delta \mathrm{H}=+206 \mathrm{~kJ} / \mathrm{mol}
$$

3) Water gas shift reaction [8]

$$
\mathrm{CO}+\mathrm{H}_{2} \mathrm{O}=\mathrm{H}_{2}+\mathrm{CO}_{2} \quad \Delta \mathrm{H}=-41 \mathrm{~kJ} / \mathrm{mol}
$$

4) Preferential oxidation reaction [9]

$$
\begin{array}{ll}
\mathrm{CO}+0.5 \mathrm{O}_{2}=\mathrm{CO}_{2} & \Delta \mathrm{H}=-280 \mathrm{~kJ} / \mathrm{mol} \\
\mathrm{H}_{2}+0.5 \mathrm{O}_{2}=\mathrm{H}_{2} \mathrm{O} & \Delta \mathrm{H}=-240 \mathrm{~kJ} / \mathrm{mol}
\end{array}
$$

5) Methanation reaction [10]

$$
\begin{array}{ll}
\mathrm{CO}_{2}+4 \mathrm{H}_{2}=\mathrm{CH}_{4}+2 \mathrm{H}_{2} \mathrm{O} & \Delta \mathrm{H}=-165 \mathrm{~kJ} / \mathrm{mol} \\
\mathrm{CO}+3 \mathrm{H}_{2}=\mathrm{CH}_{4}+2 \mathrm{H}_{2} \mathrm{O} \quad \Delta \mathrm{H}=-206 \mathrm{~kJ} / \mathrm{mol}
\end{array}
$$

\subsection{Apparatus}

Figure 1 shows gliding arc plasma reforming system. The equipment is composed of gliding arc plasma reforming system, power supply, gas/steam supply line, measurement/analysis equipment, and control/monitoring system.

Gliding arc plasma reforming system can be divided into gliding arc plasma-catalysis reactor, water gas shift reactor, and preferential oxidation reactor. The specifications for the gliding arc plasma reforming system are shown in Table 1.

Gliding arc plasma-catalysis reactor is an integrated system of Gliding arc plasma reactor and catalyst reactor. Gliding arc plasma reactor features 3 fan-shaped electrodes in 120 degrees. Ceramic $\left(\mathrm{Al}_{2} \mathrm{O}_{3}\right.$ wt $\left.96 \%\right)$ is used for insulation and fixing electrode with $4 \mathrm{~mm}$ gap. Gas jet nozzle in $3 \mathrm{~mm}$ diameter is installed above of electrode, and outer shell of gliding arc plasma reactor is made of quartz tube to check the inside. Catalyst reactor is made of triple shell for the equal pre-heating of catalyst with $2 \mathrm{~mm}$ diameter. Spherical alumina $\left(\gamma-\mathrm{Al}_{2} \mathrm{O}_{3}\right)$ is used as carrier, and commercial nickel catalyst made through impregnation method. Characteristics of catalyst by reactors are shown in Table 2 .

Water gas shift reactor is composed of high temperature shift (HTS) reactor and low temperature shift (LTS) reactor with double shell structure. Waste heat from gliding arc plasma-catalysis reactor is passed through HTS and LTS, sequentially. This will maintain the temperature of catalyst bed. In addition, porous distributor is installed to equal and homogeneous contact of reforming gas at the inside of bed. Heat exchanger is installed between HTS and LTS, and air is introduced to control the temperature between reactors. Capacity of reactor is designed to be $0.8 \mathrm{~L}$, and volume of catalyst bed is $0.4 \mathrm{~L}$.

Preferential oxidation reactor is composed of PROX I (preferential oxidation I) and PROX II (preferential oxidation II). Catalyst bed in stage I is supported by metal tube, and reforming gas is designed to be well spread after shift reactor. At the inside, spiral heat exchanger is installed to control the internal temperature, and reactor capacity is $0.4 \mathrm{~L}$. For the stage II, distribution panel is installed to equal input into catalyst bed and uniform contact with oxygen. Its capacity is $0.2 \mathrm{~L}$.

The premixed burner was used in order to supply the heat source of the water gas shift reactor and steam generator. Burner capacity is $1.4 \mathrm{~L}$ and it is composed of igniter and distributer with ceramic honeycomb. Fuel $\left(\mathrm{C}_{3} \mathrm{H}_{8}\right)$ and air were mixed and then, it was burned by the igniter after passing the distributer.

Power supply (Unicon Tech, UAP-15K1A, Korea) is implemented for the stabilized plasma with $15 \mathrm{~kW}$ of 


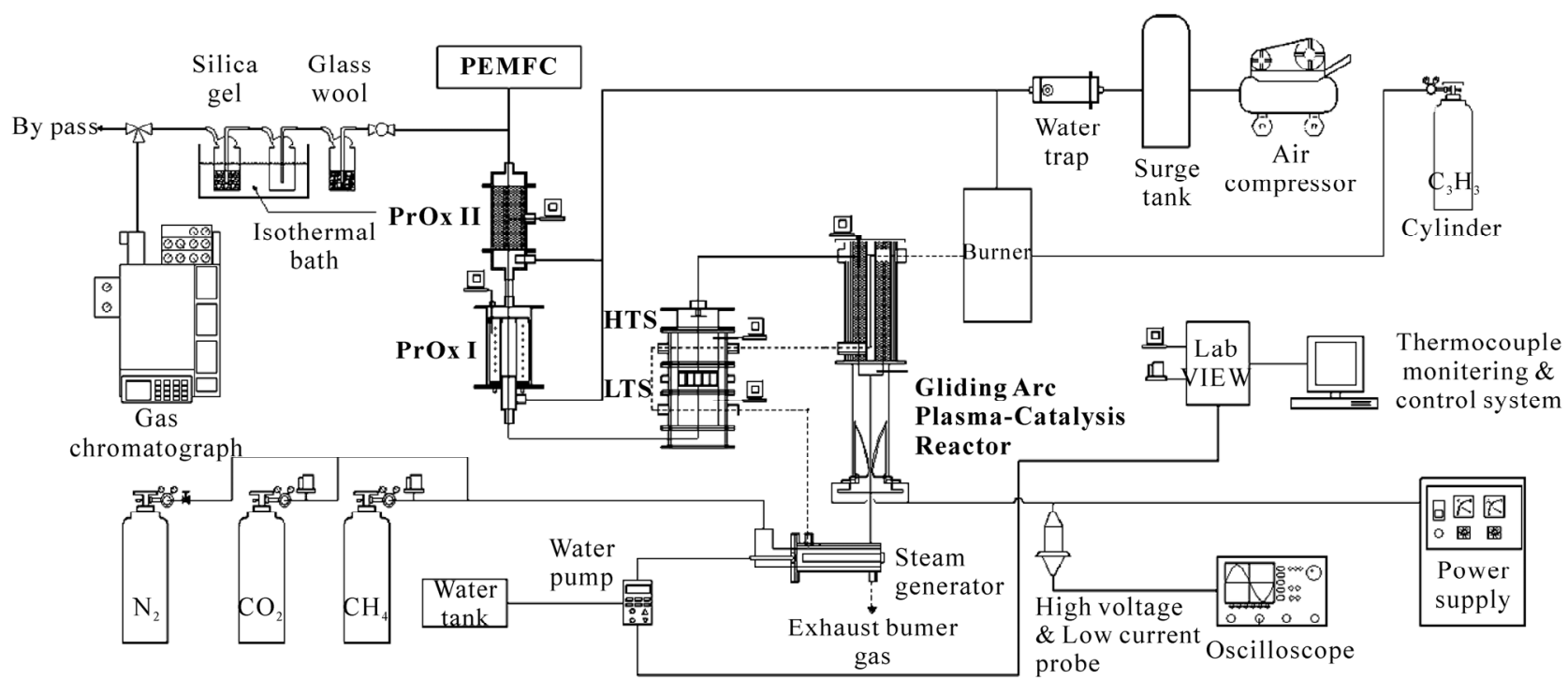

Figure 1. Schematic of the experiment setup for gliding arc plasma system.

Table 1. Gliding arc plasma generating system.

\begin{tabular}{|c|c|c|c|c|c|}
\hline System parts & Reactor stage & Capacity of reactor & Volume of catalyst bed & Shape & Features \\
\hline \multirow{2}{*}{$\begin{array}{l}\text { Gliding arc } \\
\text { plasma-catalysis } \\
\text { reactor }\end{array}$} & $\begin{array}{l}\text { Gliding arc plasma } \\
\text { reactor }\end{array}$ & 0.6 & - & Cylinder & $\begin{array}{l}\text { - } 3 \text { fan shaped electrodes } \\
\text { - Gas jet nozzle } \\
\text { - Ceramic insulator }\end{array}$ \\
\hline & Catalyst reactor & 0.7 & 0.4 & $\begin{array}{l}\text { Triple shell } \\
\text { Cylinder }\end{array}$ & - Heat exchanger \\
\hline \multirow{2}{*}{$\begin{array}{l}\text { Water gas shift } \\
\text { reactor }\end{array}$} & HTS & 0.8 & 0.4 & \multirow{2}{*}{$\begin{array}{l}\text { Double shell } \\
\text { cube }\end{array}$} & \multirow{2}{*}{$\begin{array}{l}\text { - Porous distributor } \\
\text { - Heat exchanger }\end{array}$} \\
\hline & LTS & 0.8 & 0.4 & & \\
\hline \multirow{2}{*}{$\begin{array}{l}\text { Preferential } \\
\text { oxidation reactor }\end{array}$} & PROX I & 0.4 & 0.15 & Cylinder & $\begin{array}{l}\text { - Metal mesh tube } \\
\text { - Spiral heat exchanger }\end{array}$ \\
\hline & PROX II & 0.35 & 0.2 & Cylinder & - Distribution panel \\
\hline
\end{tabular}

Table 2. Characteristics of commercial catalysts.

\begin{tabular}{lccccc}
\hline \multicolumn{1}{c}{ Reactor stage } & Catalysis reactor & HTS & LTS & PROX I & PROX II \\
\hline Shape & Sphere & Pellet & Pellet & Sphere & Sphere \\
Size & $\mathrm{OD} ; 2 \mathrm{~mm}$ & $3.2 \times 3.2 \mathrm{~mm}$ & $3.2 \times 3.2 \mathrm{~mm}$ & OD; $2 \mathrm{~mm}$ & OD; $2 \mathrm{~mm}$ \\
Composition & $\mathrm{NiO}$ & $\mathrm{Fe}_{2} \mathrm{O}_{3}: \mathrm{Cr}_{2} \mathrm{O}_{3}: \mathrm{CuO}$ & $\mathrm{Cu}: \mathrm{Zn}$ & $\mathrm{Pt}$ & $(2 \mathrm{wt} \%)$ \\
Manufacturer & $(10-14 \mathrm{wt} \%)$ & $(80: 8.5: 2 \mathrm{wt} \%)$ & $(40-44: 44-50 \mathrm{wt} \%)$ & $(1.8-2 \mathrm{wt} \%)$ & Süd-Chemie \\
\hline
\end{tabular}

maximum capacity (voltage: $15 \mathrm{kV}, \mathrm{AC}: 1 \mathrm{~A}$ ).

Gas/steam supply line is made of $\mathrm{CH}_{4} \mathrm{MFC}$ (LINETECH, $\mathrm{M} 3030 \mathrm{~V}$, Korea) and $\mathrm{CO}_{2}$ MFC (BRONKHOST, F201AC-FAC-22-V, Netherlands) for the precise control on gas flow rate. Air to preferential oxidation reactor is fed through MFC (LINETECH, M3030V, Korea). Steam is generated from water supply with feed pump (KNF, STEPDOS $^{\circledR}$ 03, Switzerland).

Measurement and analysis equipments for plasma discharge voltage and current are consisted of high volt- age probe (Tektronix, P6015, USA) and current probe (Tektronix, A6303, USA) along with oscilloscope (TDS 3052, USA). K-type thermocouple is used to measure the temperature via LabVIEW. Internal temperature of plasma is monitored in real time with device (KIMO, KTT300, USA).

For gas analysis, gas chromatography with sampling line (SHIMAZU, GC-14B, Japan) and micro-gas chromatography (VARIAN, CP-4900, Netherlands) are adopted to analyze $\mathrm{H}_{2}, \mathrm{CO}$, and $\mathrm{C}_{\mathrm{n}} \mathrm{H}_{\mathrm{m}}$ at the same time. 
As control and monitoring system, LabVIEW (National Instrument, LabVIEW 8.6, USA) is utilized to control MFC, water pump, and heater. In addition, change in temperature and experimental conditions are monitored continuously.

\subsection{Experimental Methods}

Temperature of steam generator, which is installed at the prior to gas feed in gliding arc plasma-catalysis reactor, is maintained at $290^{\circ} \mathrm{C}$, and temperature of catalyst bed is sustained up to $680^{\circ} \mathrm{C}$ using external burner. $2.4 \mathrm{~kW}$ of input electric power is formed in stable, and $12 \mathrm{~L} / \mathrm{min}$ of steam, $2.4 \mathrm{~L} / \mathrm{min}$ of $\mathrm{CH}_{4}$, and $1.6 \mathrm{~L} / \mathrm{min}$ of $\mathrm{CO}_{2}$ are introduced to conduct the experiment on optimal operation conditions in gliding arc plasma reforming system. The initial temperature characteristics of reactor are shown in Figure 2.

$\mathrm{CH}_{4}$ and $\mathrm{CO}_{2}$ that were used in the experiment were fed via MFC for flow rate control. Steam is controlled via water feed pump through calculation on the conversion rate from water to steam. After that, steam is introduced to steam generator along with fuel, and entered into reactor as completely vaporized gas.

Collection of reforming gas is made through sampling port on the discharging portion of reactor. Particulate is removed from collected sample via impinge, and moisture is condensed through cooling unit. As dry gas state, the gas is continuously introduced into each sampling loop of gas chromatography. TCD detector is adopted, and molecular sieve $5 \mathrm{~A}$ (Shimadzu) for $\mathrm{H}_{2}$ and Porapak $\mathrm{Q}$ (Varian) for $\mathrm{C}_{2} \mathrm{H}_{4}, \mathrm{C}_{2} \mathrm{H}_{6}, \mathrm{CO}_{2}$ are used as analysis column.

As standard condition, steam feed of HTS and LTS in water gas shift reactor is changed to find the optimal condition of steam/carbon ratio. In addition, the experiment that is aimed to determine optimal catalyst bed temperature was conducted. For preferential oxidation reactor, air input flow rate of PROX I and PROX II was varied to find the optimal operating condition including the temperature change in catalyst bed.

\subsection{Error Analysis}

Table 3 shows the calibrated range, accuracy and relative error of measurement. Errors in experiments can arise from observation, reading and test planning. The accuracy of the experiments has to be validated with an error analysis. That was done by using the method of average value of data was calculated by results of identical experimental condition. Then each data were analyzed by polynomial regression. For a given data set of $\mathrm{x}$, $\mathrm{y}$ pairs, a polynomial regression of this kind can be generated as the Equation (10), Standard error $\left(S_{y / x}\right)$ was

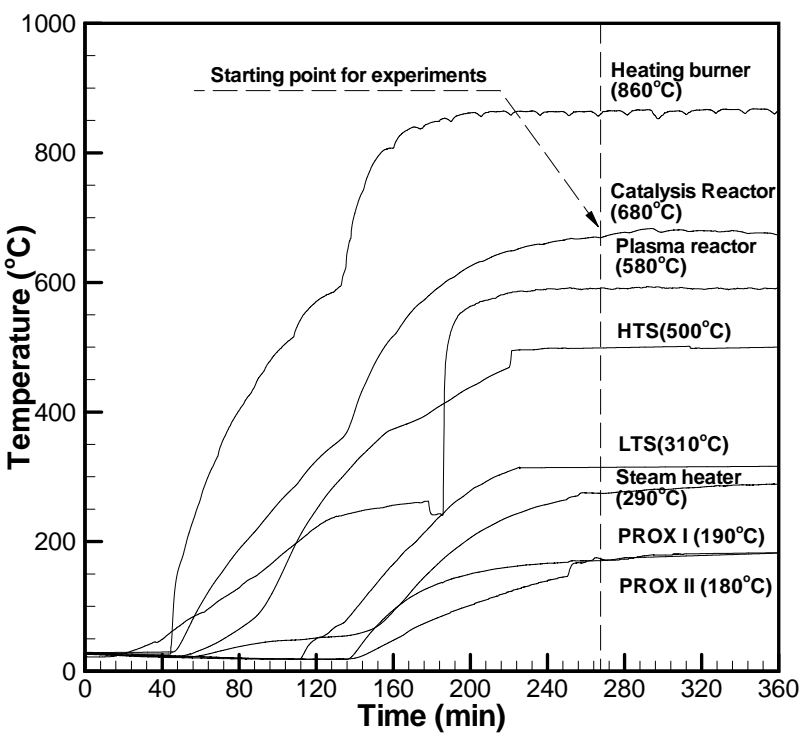

Figure 2. Initial operating characteristics of the reactor.

calculated by Equation (11)

$$
\begin{gathered}
y=a_{0}+a_{1} x+a_{2} x^{2}+a_{3} x^{3}+a_{4} x^{4}+\cdots \\
S_{y / x}=\sqrt{\frac{\sum_{i=1}^{n}\left(y_{i}-a_{0}-a_{1} x_{i}-a_{2} x_{i}^{2}\right)^{2}}{n-(m+1)}}
\end{gathered}
$$

\section{Results and Discussion}

\subsection{Overall Reactor Concentration for Standard Condition}

As biogas composition for the experiment, $6: 4$ for $\mathrm{CH}_{4}$ : $\mathrm{CO}_{2}$, which is similar to landfill biogas, is selected. Through repeated and preliminary experimentation, 2.4 $\mathrm{kW}$ of input electric power, 3 of $\mathrm{S} / \mathrm{C}$ ratio, $680^{\circ} \mathrm{C}$ of catalyst bed temperature in gliding arc plasma-catalysis reactor, and $16 \mathrm{~L} / \mathrm{min}$ of total gas flow rate are used to achieve stabilized plasma discharge and $62 \%$ of hydrogen production. In addition, the corresponding temperature of HTS, LTS, PROX I, and PROX II was maintained as $500^{\circ} \mathrm{C}, 340^{\circ} \mathrm{C}, 190^{\circ} \mathrm{C}$, and $190^{\circ} \mathrm{C}$. Air feed to PROX reactor was $300 \mathrm{~mL} / \mathrm{min}$ for stage I and 200 $\mathrm{mL} / \mathrm{min}$ for stage II. The relevant test results are included in Table 4 .

Figure 2 shows the concentration of major gas in each reactor. Concentration of reformed $\mathrm{H}_{2}$ and $\mathrm{CO}$ in gliding arc plasma-catalysis reactor was $62.1 \%$ and $11.7 \%$, respectively. For HTS, it was $64.1 \%$ and $11.6 \%$, and LTS showed $64.3 \%$ and $6.0 \%$ of concentration level. Hydrogen concentration after each reactor is increased according to Equations (4) and (5). In addition, decrease in $\mathrm{CO}$ concentration is also determined. For PROX I, $\mathrm{H}_{2}, \mathrm{CO}$, 
Table 3. Calibrated range, accuracy and relative error of measurement.

\begin{tabular}{llccc}
\hline \multicolumn{1}{c}{ Measurement } & \multicolumn{1}{c}{ Equipment } & Calibrated range & Accuracy & Relative error (\%) \\
\hline Mass flow controller $\left(\mathrm{CH}_{4}\right)$ & Line tech, M3030V & $0-10 \mathrm{~L} / \mathrm{min}$ & $\pm 1 \%$ & \pm 0.25 \\
Mass flow controller $\left(\mathrm{CO}_{2}\right)$ & Bronkhorst, F201AC-FAC-22-V & $0-15 \mathrm{~L} / \mathrm{min}$ & $\pm 0.1 \%$ & \pm 0.01 \\
Diaphragm metering pump & Knf, STEPDOS ${ }^{\circledR} 03$ & $0-20 \mathrm{~mL} / \mathrm{min}$ & $\pm 1.9 \%$ & \pm 1 \\
Thermocouple temperature datalogger & Kimo, KTT300 & $-200^{\circ} \mathrm{C}-1000^{\circ} \mathrm{C}$ & $\pm 1.1^{\circ} \mathrm{C}$ & \pm 0.4 \\
High voltage & Tektronix, P6015A & $1.5-20 \mathrm{kV}$ & $\pm 1 \mathrm{~V}$ & \pm 0.005 \\
Current & Tektronix, A6303 & $0-100 \mathrm{~A}$ & $\pm 5 \mathrm{~mA}$ & \pm 0.01 \\
\hline
\end{tabular}

Table 4. Range of the various experiments.

\begin{tabular}{cccccc}
\hline Experiment variables & Steam/carbon ratio & $\begin{array}{c}\text { Catalyst bed } \\
\text { temperature }\left({ }^{\circ} \mathrm{C}\right)\end{array}$ & $\begin{array}{c}\text { Total gas flow rate } \\
(\mathrm{L} / \mathrm{min})\end{array}$ & $\begin{array}{c}\text { Input electric power } \\
(\mathrm{kW})\end{array}$ & $\begin{array}{c}\text { Biogas component } \\
\text { ratio }\left(\mathrm{CH}_{4}: \mathrm{CO}_{2}\right)\end{array}$ \\
\hline Range & 3 & 700 & 16 & 2.4 & $6: 4$ \\
Reactor & $\begin{array}{c}\text { Gliding arc } \\
\text { plasma-catalysis reactor }\end{array}$ & HTS & LTS & PROX I & PROX II \\
$\mathrm{H}_{2}$ & $62.1 \%$ & $64.1 \%$ & $64.3 \%$ & $64.2 \%$ & $57.5 \%$ \\
$\mathrm{CO}$ & $11.7 \%$ & $11.6 \%$ & $6.0 \%$ & $9400 \mathrm{ppm}$ & $7 \mathrm{ppm}$ \\
\hline
\end{tabular}

and $\mathrm{CH}_{4}$ shows $64.2 \%, 9400 \mathrm{ppm}$, and $2 \%$, respectively. PROX II displayed $57.5 \%, 7 \mathrm{ppm}$, and $3 \%$ for $\mathrm{H}_{2}, \mathrm{CO}$, and $\mathrm{CH}_{4}$. During the passing PROX reactor, decrease in concentration of $\mathrm{CO}$ and $\mathrm{H}_{2}$ will be happened. Air input will induce $\mathrm{CO}$ oxidation reaction (Equation (6)), hydrogen oxidation (Equation (7)), and methanization reaction (Equations (8) and (9)) at the same time. Therefore, concentration level of $\mathrm{CO}$ and $\mathrm{H}_{2}$ was decreased along with the increase in $\mathrm{CH}_{4}$ level. In the standard condition, final concentration of $\mathrm{CO}$ is $7 \mathrm{ppm}$, which is lower than the deactivation of fuel cell electrode. Application on PEMFC is viable.

\subsection{Parametric Researches}

$\mathrm{CO}$ concentration from gliding arc plasma reactor is $12 \%$ in average, and introduction to PEMFC will cause the catalyst deactivation of electrode. Therefore, the concentration of reforming gas should be reduced to less than $10 \mathrm{ppm}$ before the introduction to PEMFC. In addition, the corresponding design and preparation of water gas shift reactor and preferential oxidation reactor was conducted. Steam feed amount and catalyst bed temperature change in HTS and LTS in water gas shift reactor and air input flow rate and catalyst bed temperature change in PROX I and PROX II in preferential oxidation reactor were studied.

\subsubsection{Water Gas Shift Reactor}

1) Effect of steam feed amount in HTS and LTS

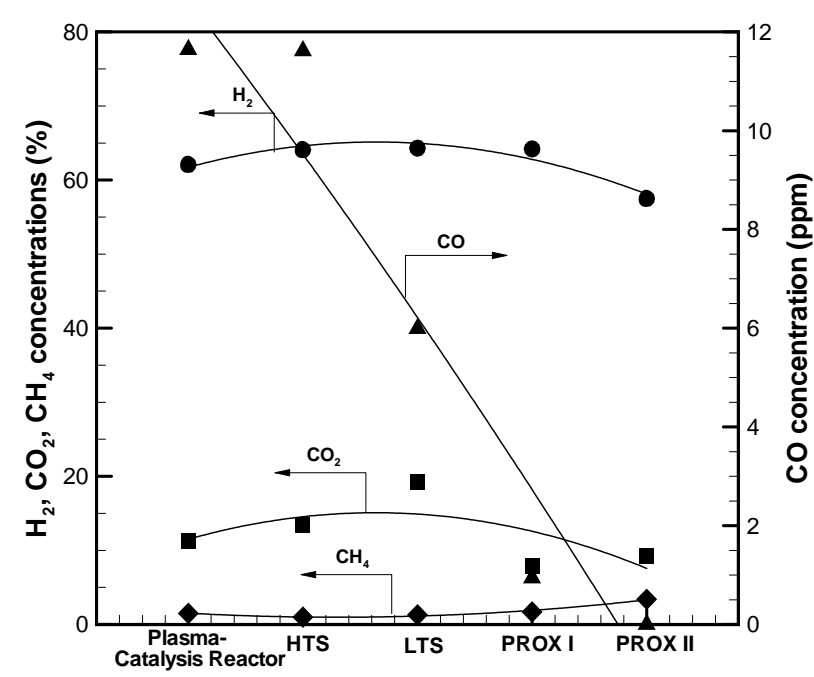

Figure 3. The corresponding concentration of syngases in reactor.

Figure 4 shows the change in steam feed of HTS and LTS. Temperatures of catalyst bed, HTS, and LTS in gliding arc plasma-catalysis reactor are maintained as $680^{\circ} \mathrm{C}, 500^{\circ} \mathrm{C}$, and $310^{\circ} \mathrm{C}$, respectively. Feed of $\mathrm{CH}_{4}$ and $\mathrm{CO}_{2}$ is $2.4 \mathrm{~L} / \mathrm{min}$ and $1.6 \mathrm{~L} / \mathrm{min}$ when input electric power and total gas flow rate is set to $2.4 \mathrm{~kW}$ and 16 $\mathrm{L} / \mathrm{min}$.

Water gas shift reactor is designed to use steam feed amount for gliding arc plasma-catalysis reactor, and carbon black is formed when less than 2 of $\mathrm{S} / \mathrm{C}$ ratio in gliding arc plasma-catalysis reactor. For more than 4 of 
$\mathrm{S} / \mathrm{C}$ ratio, temperature reduction from steam generator was exhibited by the increased amount of water. With consideration on these issues, 2.6 - 3.4 of $\mathrm{S} / \mathrm{C}$ ratio, which shows the steady formation of discharge gas from gliding arc plasma catalyst reactor was adopted in the experiment.

Figure 4(a) represents the major gas concentrations according to steam feed in HTS. CO concentration from gliding arc plasma-catalysis reactor displayed $14 \%$ in average, and the concentration was reduced to $11 \%$ after HTS. In addition, $\mathrm{H}_{2}$ concentration was maintained at $63 \%$ in average. 3 in $\mathrm{S} / \mathrm{C}$ ratio shows the maximum value, $65 \%$.

Figure 4(b) shows the major gas concentrations by steam feed amount in LTS. CO concentration from HTS

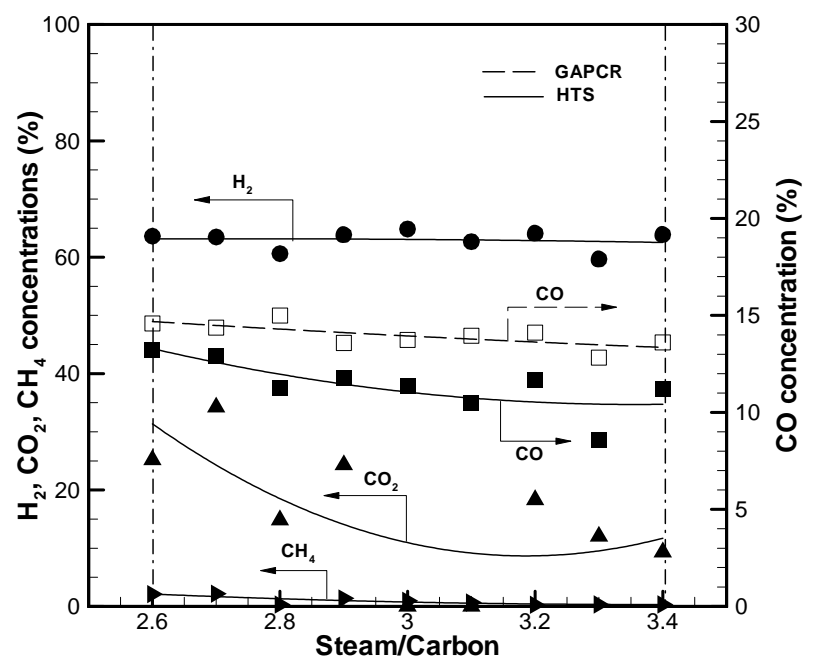

(a)

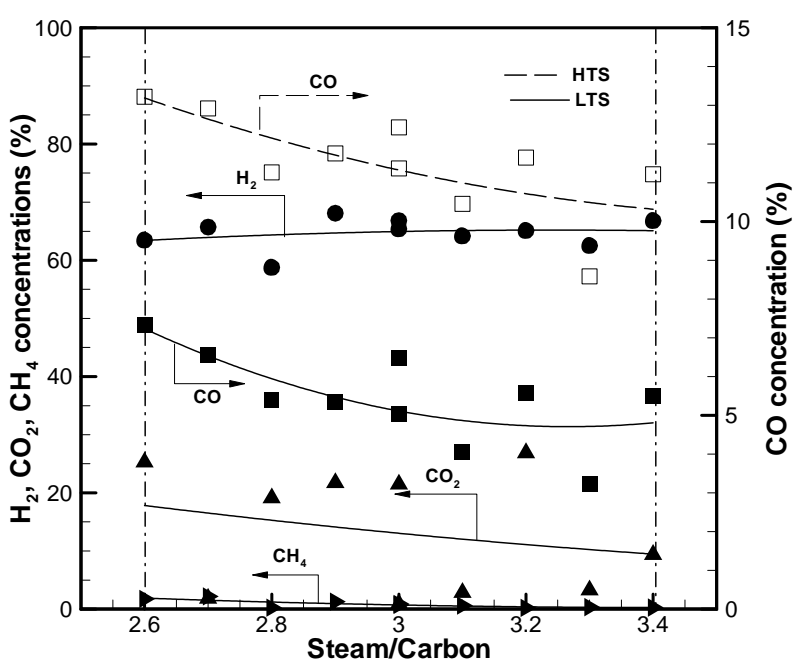

(b)

Figure 4. The effect of the various S/C ratios. (a) Concentration of syngases on HTS; (b) Concentration of syngases on LTS. reactor displays $11 \%$ in average, and it is further reduced to $5 \%$ after LTS. In addition, increase in steam feed amount will cause the reduction of $\mathrm{CO}$ concentration. This can be elucidated by Equation (5), facilitated reaction between $\mathrm{CO}$ and $\mathrm{H}_{2} \mathrm{O}$ by the catalyst in LTS. For $\mathrm{H}_{2}$ concentration, $65 \%$ in average was determined $(2 \%$ increase from HTS), and 2.9 of $\mathrm{S} / \mathrm{C}$ ratio shows the maximum, $68 \%$.

2) Effect of HTS and LTS catalyst bed temperature

Figure 5 shows the temperature change in HTS and LTS catalyst bed. S/C ratio of HTS and LTS reactor in gliding arc plasma-catalyst reactor is maintained as 3, and $\mathrm{CH}_{4}$ and $\mathrm{CO}_{2}$ feed are $2.4 \mathrm{~L} / \mathrm{min}$ and $1.6 \mathrm{~L} / \mathrm{min}$. Input electric power to gliding arc plasma is $2.4 \mathrm{~kW}$, and total gas flow rate is set to $16 \mathrm{~L} / \mathrm{min}$.

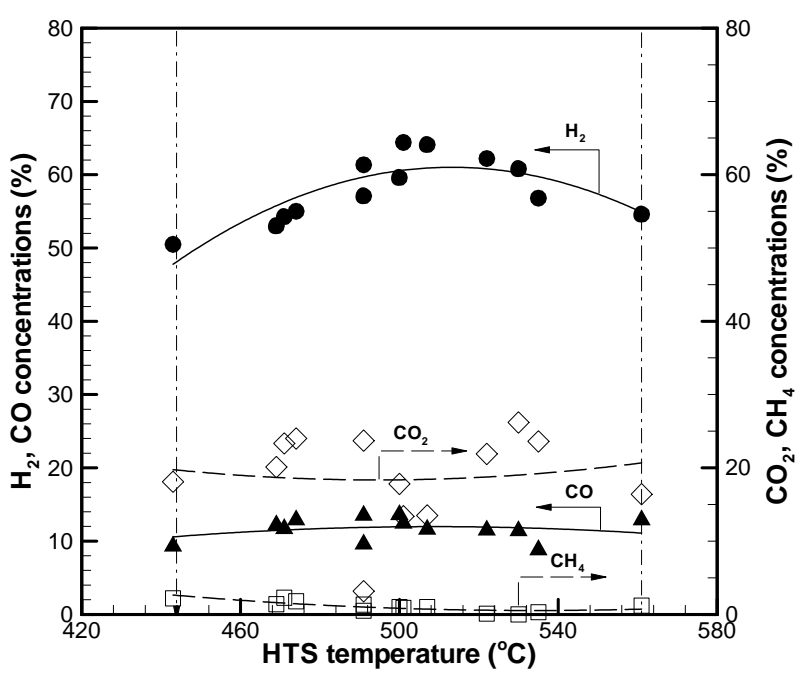

(a)

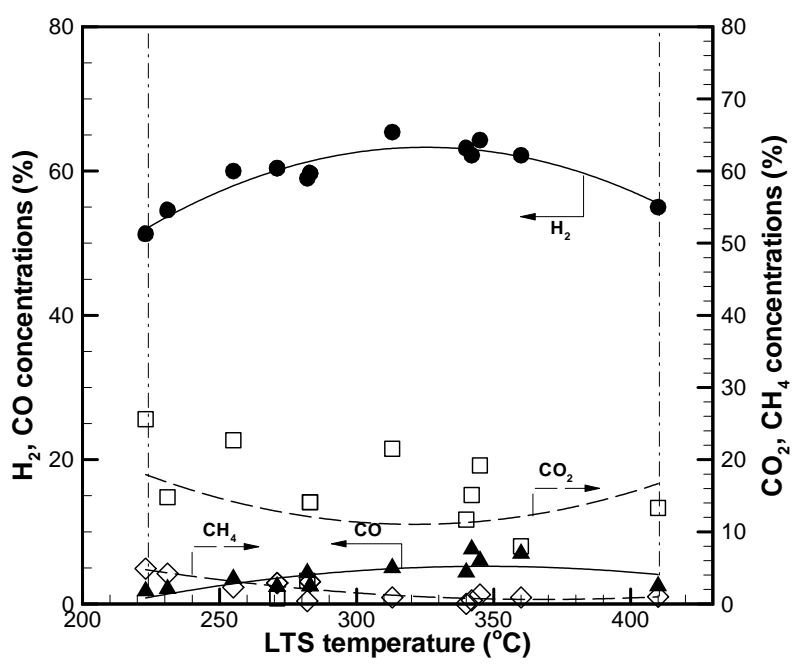

(b)

Figure 5. The effect of various catalyst bed temperature. (a) Concentration of syngases on HTS; (b) Concentration of sysgases on LTS. 
HTS catalyst bed temperature. Under $440^{\circ} \mathrm{C}$, there is a minimal reaction because of less than $600^{\circ} \mathrm{C}$ of gliding arc plasma-catalysis reactor catalyst bed temperature. For higher than $560^{\circ} \mathrm{C}$, catalyst bed will be damaged. Therefore, $440^{\circ} \mathrm{C}-560^{\circ} \mathrm{C}$ of temperature range is set for the experiments.

According to the increase in catalyst bed temperature, $\mathrm{H}_{2}$ concentration will be gradually increased, and $500^{\circ} \mathrm{C}$ showed the maximum value, $64 \%$. Temperature higher than $500^{\circ} \mathrm{C}$ shows the decrease in concentration. For $\mathrm{CO}$ concentration, it is stable at $12 \%$ in average. Where, $\mathrm{CH}_{4}$ displays $1 \%$ in average, and the most of $\mathrm{CH}_{4}$ is converted.

Figure 5(b) exhibits the major gas concentration according to LTS catalyst bed temperature. Catalyst bed temperature in $\mathrm{HTS}$ is set to $500^{\circ} \mathrm{C}$, and heat exchanger is utilized between HTS and LTS reactor. LTS catalyst bed temperature is adjusted to $220^{\circ} \mathrm{C}-410^{\circ} \mathrm{C}$ for experiment.

When the catalyst bed temperature increases, the maximum level of hydrogen as $65 \%$ is achieved at $310^{\circ} \mathrm{C}$. Where, $\mathrm{CO}, \mathrm{CO}_{2}$, and $\mathrm{CH}_{4}$ are displayed as $5 \%, 22 \%$, and $0.9 \%$. Above this temperature, the concentration is gradually reduced. LTS catalyst is determined to be active at $310^{\circ} \mathrm{C}$ according to Equation (5).

For LTS, $14 \%$ of difference in $\mathrm{H}_{2}$ is reported according to catalyst bed temperature. In addition, $\mathrm{CO}$ concentration seems to have large variation as $6 \%$ in average, and LTS catalyst bed is significantly affected by temperature.

\subsubsection{Preferential Oxidation Reactor}

$\mathrm{CO}$ concentration level after water gas shift reactor is about $5 \%$. This will cause deactivation of electrode in PEMFC, and preferential oxidation reactor is implemented to lower the concentration by $10 \mathrm{ppm}$. In addition, Pt-based catalyst and Ru-based catalyst are filled in stage 1 and 2 , respectively.

1) Effect of air feed in preferential oxidation reactor

Figure 6 shows the air feed change in preferential oxidation reactor. Temperatures of gliding arc plasma reactor-catalysis reactor catalyst bed $680^{\circ} \mathrm{C}$, HTS/LTS reactor are maintained as $500^{\circ} \mathrm{C}$ and $310^{\circ} \mathrm{C} . \mathrm{CH}_{4}$ and $\mathrm{CO}_{2}$ feed is $2.4 \mathrm{~L} / \mathrm{min}$ and $1.6 \mathrm{~L} / \mathrm{min}$, respectively. Input electric power of gliding arc plasma is $2.4 \mathrm{~kW}$, and total gas flow rate is $16 \mathrm{~L} / \mathrm{min}$. The $\mathrm{S} / \mathrm{C}$ ratio is set to 3 . In addition, temperature of PROX I and PROX II is $190^{\circ} \mathrm{C}$ and $190^{\circ} \mathrm{C}$.

Figure 6(a) shows the gas concentration change according to air input flow rate in PROX I. When the air input flow rate is increased, $\mathrm{H}_{2}$ concentration is reduced from $64 \%$ to $48 \%$. According to Equation (7), hydrogen is reacted with $\mathrm{CO}$ and remained oxygen. In addition, the nitrogen component in air will dilute the hydrogen concentration. For CO concentration, $21000 \mathrm{ppm}$ is achieved at the initial stage with $100 \mathrm{~mL} / \mathrm{min}$, and the level is reduced to $2500 \mathrm{ppm}$ upon the introduction of $500 \mathrm{~mL} / \mathrm{min}$. The optimal condition, $300 \mathrm{~mL} / \mathrm{min}$, which shows the significant drop in $\mathrm{CO}$ concentration and steady production of $\mathrm{H}_{2}$, is determined. Where, major gas concentrations exhibit $64 \%$ of $\mathrm{H}_{2}, 9400 \mathrm{ppm}$ of $\mathrm{CO}$, and $2 \%$ of $\mathrm{CH}_{4}$.

Figure 6(b) shows the major gas concentration change by air input flow rate in PROX II. From the optimal condition at PROX I, $300 \mathrm{~mL} / \mathrm{min}, 100-300 \mathrm{~mL} / \mathrm{min}$ of air is introduced at PROX II. When air input flow rate is increased, $\mathrm{H}_{2}$ concentration is reduced from $59 \%$ to $43 \%$. For $\mathrm{CO}$, the concentration is reduced from $3400 \mathrm{ppm}$ to 0 ppm.

For the optimal air input flow rate condition, $200 \mathrm{~mL} /$ min, which shows no reduction in $\mathrm{H}_{2}$ concentration along with less than $10 \mathrm{ppm}$ of $\mathrm{CO}$, is determined. $\mathrm{H}_{2}$ concentration at the optimal condition is $58 \%$, and $7 \mathrm{ppm}$ of $\mathrm{CO}$ is reported. For $\mathrm{CO}_{2}$ and $\mathrm{CH}_{4}, 14 \%$ and $3 \%$ is displayed. When the air input flow rate increases, $\mathrm{CO}$ level will be decreased. In addition, $\mathrm{CO}_{2}$ and $\mathrm{CH}_{4}$ level will be raised. According to Equation (6), $\mathrm{CO}$ will be depleted, and $\mathrm{CH}_{4}$ is reformed by Equation (9), methanation.

2) Effect of temperature in preferential oxidation reactor

Figure 7 shows the change in catalyst bed temperature in preferential oxidation reactor. Temperature of gliding arc plasma-catalysis reactor catalyst bed, HTS, and LTS reactor is set to $680^{\circ} \mathrm{C}, 500^{\circ} \mathrm{C}$, and $310^{\circ} \mathrm{C}$, respectively. Input $\mathrm{CH}_{4}$ and $\mathrm{CO}_{2}$ are $2.4 \mathrm{~L} / \mathrm{min}$ and $1.6 \mathrm{~L} / \mathrm{min}$, and input electric power to gliding arc plasma is set to 2.4 $\mathrm{kW}$. Total gas flow rate is $16 \mathrm{~L} / \mathrm{min}$ with 3 of $\mathrm{S} / \mathrm{C}$ ratio. In addition, air input flow rate to PROX I and PROX II is $300 \mathrm{~mL} / \mathrm{min}$ and $200 \mathrm{~mL} / \mathrm{min}$, respectively.

Figure 7(a) represents the major gas concentration changes according to catalyst bed temperature of PROX I. As per the increase in temperature, $\mathrm{H}_{2}$ level is gradually increased, and shows the maximum, $62 \%$ at $190^{\circ} \mathrm{C}$. Where, $\mathrm{CO}$ shows the minimum, $2200 \mathrm{ppm}$, and $3 \%$ of $\mathrm{N}_{2}, 9 \%$ of $\mathrm{CO}_{2}$, and $3 \%$ of $\mathrm{CH}_{4}$ are achieved. In case of less than $190^{\circ} \mathrm{C}$, low temperature of catalyst bed causes the lower hydrogen level from air dilution rather than the reaction by Equation (6). For the higher than $190^{\circ} \mathrm{C}, \mathrm{H}_{2}$ concentration is decreased by methanation in Equation (8). The significant difference in concentration level for $\mathrm{H}_{2}$ and CO suggests the higher sensitivity of PROX I catalyst on temperature.

Figure $\mathbf{7 ( b )}$ shows the major gas concentration changes in catalyst bed of PROX II. Temperature of PROX I is set to $190^{\circ} \mathrm{C}$, and the temperature range of 


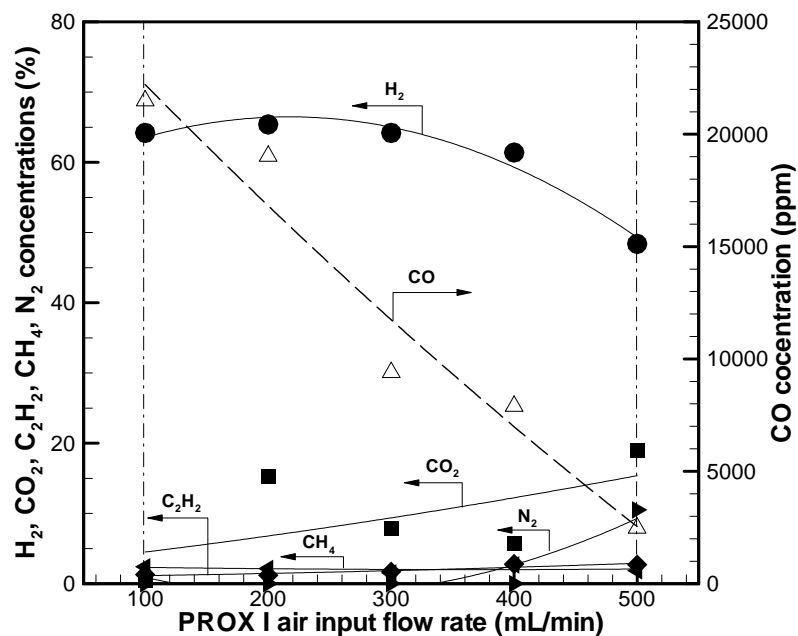

(a)

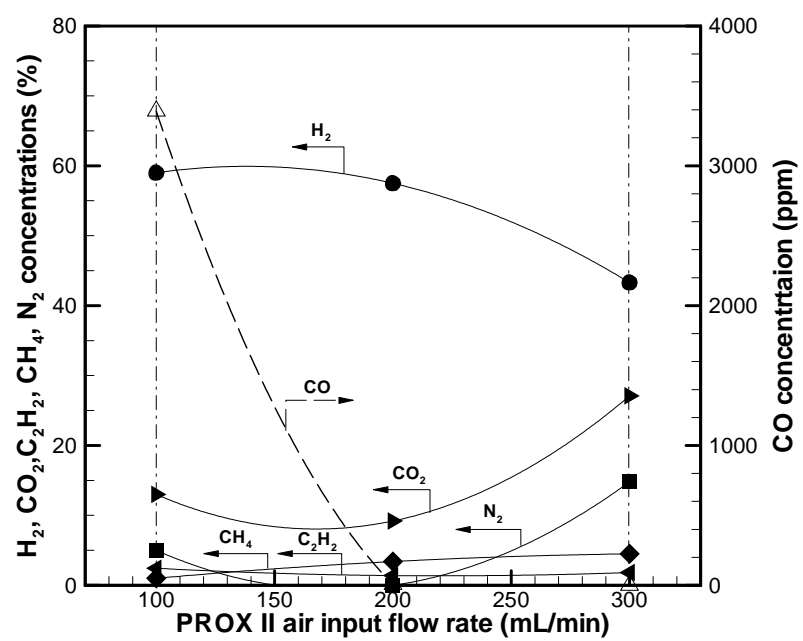

(b)

Figure 6. The effect of the various air input flow rate. (a) Concentration of syngases on PROX I; (b) Concentration of syngases on PROX II.

PROX II is changed from $70^{\circ} \mathrm{C}-190^{\circ} \mathrm{C}$ for experiment.

As the temperature of catalyst bed increases, hydrogen concentration shows the maximum value of $58 \%$ at $190^{\circ} \mathrm{C}$, where $\mathrm{CO}, \mathrm{CO}_{2}$, and $\mathrm{CH}_{4}$ displays 7 ppm, 9\%, and $3 \%$. When the catalyst bed temperature is low, $\mathrm{CO}$ concentration shows the significant decrease from 16000 ppm to $7 \mathrm{ppm}$ along with temperature rise. Therefore, effect of catalyst bed temperature affects significantly on CO concentration for PROX II.

In addition, $\mathrm{CH}_{4}$ concentration is increased along with hydrogen concentration according to Equation (9), methanation. The concentration of $\mathrm{C}_{2} \mathrm{H}_{2}$, one of major hydrocarbon species, is decreased from $2 \%$ to $1 \%$ along with increase in methane content. This can be explained by the formation of $\mathrm{CH}_{4}$ from the reaction of trace hydrogen from hydrocarbon and $\mathrm{CO}$.

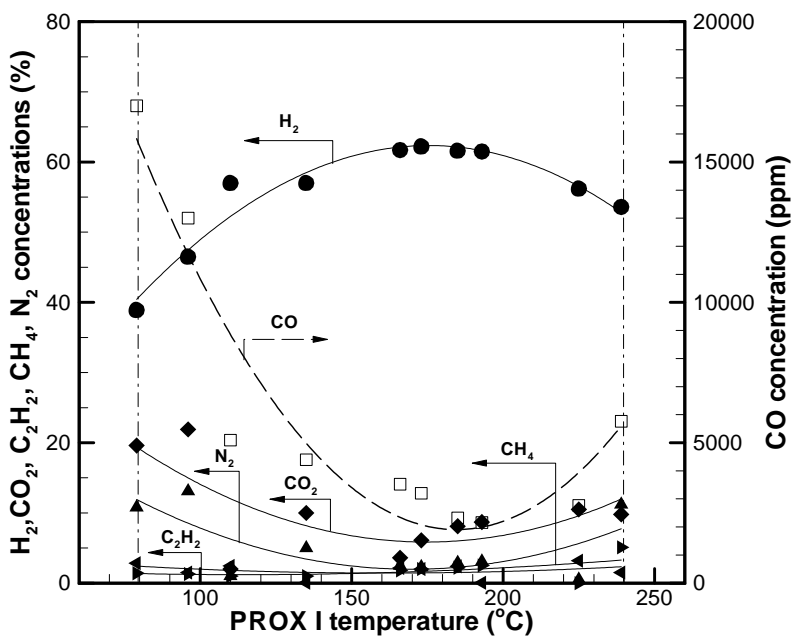

(a)

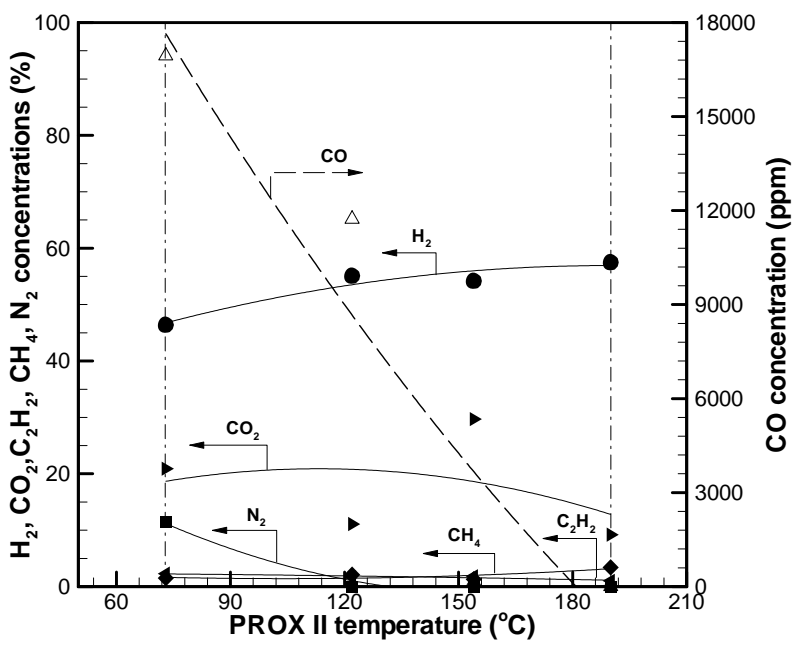

(b)

Figure 7. The effect of the various catalyst bed temperatures. (a) Concentration of syngases on PROX I; (b) Concentration of syngases on PROX II.

\section{Conclusions}

In this study, major content of biogas is reformed to $\mathrm{CH}_{4}$ and $\mathrm{CO}_{2}$ via gliding arc plasma reforming system. Specially designed and prepared system features high concentration $\mathrm{H}_{2}$ of and less than $10 \mathrm{ppm}$ of $\mathrm{CO}$. The corresponding characteristics with parameter changes were determined.

For the experiment results on biogas reforming with standard condition, gliding arc plasma-catalysis reactor, water gas shift reactor, and preferential oxidation reactor show $58 \%$ of $\mathrm{H}_{2}, 7$ ppm of $\mathrm{CO}, 9 \%$ of $\mathrm{CO}_{2}$, and $3 \%$ of $\mathrm{CH}_{4}$ in average. As with the results, the most of syngases is $\mathrm{H}_{2}$, and carbon monoxide displays less than $10 \mathrm{ppm}$, which can be applicable to PEMFC.

As the parameters that can affect the reforming per- 
formance, the steam feed amount in HTS and LTS reactor exhibits the optimal condition with 3 in $\mathrm{S} / \mathrm{C}$ ratio. Reduction of CO concentration is 3\% in average for HTS, and is further decreased to $6 \%$ after LTS reactor. Hydrogen concentration is increased to $1 \%$ after HTS and 3\% in LTS.

Effect of catalyst bed temperature in HTS and LTS exhibits the maximum point in $\mathrm{H}_{2}$ concentration as the increase in temperature. With $500^{\circ} \mathrm{C}$ in $\mathrm{HTS}$ and $310^{\circ} \mathrm{C}$ in LTS, the maximum production of $\mathrm{H}_{2}$ and low concentration of $\mathrm{CO}$ can be achieved. Catalyst bed temperature significantly affects on reforming performance.

For the air input flow rate to preferential oxidation reactor, $300 \mathrm{~mL} / \mathrm{min}$ and $200 \mathrm{~mL} / \mathrm{min}$ of PROX I and II is the optimal condition, which displays the minimum drop of $\mathrm{H}_{2}$ concentration and low $\mathrm{CO}$ content.

According to catalyst bed temperature in preferential oxidation reactor, $190^{\circ} \mathrm{C}$ of PROX I and PROX II show the optimal condition, and the temperature change affects significantly on hydrogen and $\mathrm{CO}$ concentration.

\section{References}

[1] P. Kolbitsch, C. Pfeifer and H. Hofbauer, "Catalytic Steam Reforming of Model Biogas," Fuel, Vol. 87, No. 6, 2008, pp. 701-706. doi:10.1016/j.fuel.2007.06.002

[2] S. T. Lin, Y. H. Chen, C. C. Yu, Y. C. Liu and C. H. Lee, "Modelling an Experimental Methane Fuel Processor," Journal of Power Sources, Vol. 148, 2005, pp. 43-53. doi:10.1016/j.jpowsour.2005.01.035

[3] A. Jhalani and L. D. Schmidt, "Preferential CO Oxidation in the Presence of $\mathrm{H} 2, \mathrm{H} 2 \mathrm{O}$, and $\mathrm{CO} 2$ at Short Contact-Time," Catalysis Letters, Vol. 104, No. 3-4, 2005, pp.
103-109. doi:10.1007/s10562-005-7937-9

[4] Y. N. Chun and H. O. Song, "Syngas Production Using Gliding Arc Plasma," Energy Sources, Vol. 30, No. 13, 2008, pp. 1202-1212. doi:10.1080/15567030600817670

[5] T. Sreethawong, P. Thakonpatthanakun and S. Chavadej, "Partial Oxidation of Methane with Air for Synthesis Gas Production in a Multistage Gliding Arc Discharge System," International Journal of Hydrogen Energy, Vol. 32, No. 8, 2007, pp. 1067-1079. doi:10.1016/j.ijhydene.2006.07.013

[6] A. Effendi, K. Hellgard, Z. G. Zhang and T. Yoshida, "Optimising $\mathrm{H}_{2}$ Production from Model Biogas via Combined Steam Reforming and CO Shift Reactions," Fuel, No. 84, No. 7-8, 2005, pp. 869-874. doi:10.1016/j.fuel.2004.12.011

[7] Y. N. Chun and S. C. Kim, "Production of Hydrogen-Rich Gas from Methane by Thermal Plasma Reform," Journal of the Air \& Waste management Association, Vol. 57, No. 12, 2007, pp. 1447-1451. doi:10.3155/1047-3289.57.12.1447

[8] J. D. Holladay, J. Hu, D. L. King and Y. Wang, "An Overview of Hydrogen Production Technologies," Catalysis Today, Vol. 139, No. 4, 2009, pp. 244-260. doi:10.1016/j.cattod.2008.08.039

[9] S. Srinivas, A. Dhingra, H. Im and E. Gulari, "A Scalable Silicon Microreactor for Preferential CO Oxidation Performance Comparison with a Tubular Packed-Bed Microreactor," Applied Catalysis A: General, Vol. 274, No. 1-2, 2004, pp. 285-293. doi:10.1016/j.apcata.2004.07.012

[10] Z. G. Zhang, G. Xu, X. Chen, K. Honda and T. Yoshida, "Process Development of Hydrogenous Gas Production for PEFC from Biogas," Fuel Processing Technology, Vol. 85, No. 8-10, 2004, pp. 1213-1229. doi:10.1016/j.fuproc.2003.10.017 